Eka Kadharpa Utama Dewayani ${ }^{1}$ Jurusan M anajemen, Fakultas Ekonomi dan Bisnis,U niversitas Muhammadiyah Malang

Jalan Raya Tlogomas 246 Malang Email : dewayani62@yahoo.co.id

\section{Pengembangan Potensi Ekonomi Masyarakat Terdampak Bencana Untuk Meningkatkan Ketangguhan}

https:/ / doi.org/ 10.18196/ bdr.7158

\begin{abstract}
ABSTRAK
Kota Malang merupakan salah satu daerah yang memiliki intesitas bencana seperti banjir genangan dan tanah longsor di beberapa kecamatan seperti Blimbing, Sukun, Kedungkandang, Lowokwaru, dan Klojen. Menurut Utaya Sugeng (2008) banjir genangan dan tanah longsor terjadi karena proporsi lahan terbuka di Kota Malang semakin sempit serta sistem saluran drainase yang tidak memadai (Dewanto \& Muslim, 2013). Predikat Kota Malang sebagai kota pendidikan menyebabkan semakin padatnya pemukiman. Akibatnya banjir seringkali menimbulkan kemacetan Ialu lintas, rusaknya infrastruktur jalan raya dan terganggunya aktifitas perekonomian warga. Selain itu curah hujan yang relatif tinggi pada bulan Pebruari, Nopember, Desember dengan perkiraan 201 - 300 mili meter hingga Maret 2017 (BMKG Stasiun Klimatologi Malang, 2017) menyebabkan beberapa wilayah seperti Kota Lama, Polehan, J odipan, Sukun dan Bareng sering terjadi banjir dan longsor. Disetiap musim penghujan, Kelurahan Bareng selalu mengalami bencana banjir. Bencana ini sangat berdampak pada kehidupan ekonomi masyarakat yang pada kondisinya merupakan kawasan yang termasuk dalam kategori kumuh dan padat penduduk. Penyebab bencana banjir serta dampaknya terhadap perekonomian masyarakat Kelurahan Bareng. Dari dampak tersebut akan dijelaskan tentang bagaimana pengembangan ekonomi yang kompatibel dengan keadaan dan kebutuhan masyarakat Kelurahan Bareng.
\end{abstract}

Kata kunci: potensi ekonomi, masyarakat, bencana, ketangguhan

\title{
PENDAHULUAN
}

Bencana adalah suatu peristiwa atau rangkaian kejadian yang men gakibatkan korban penderitaan manusia, kerugian harta benda, kerusakan lingkungan, sarana dan prasarana serta dapat menimbulkan gangguan terhadap tata kehidupan dan penghidupan masyarakat. Kejadian bencana selain disebabkan oleh adanya perubahan alam juga dipicu seiring meningkatnya aktivitas manusia. Intensitas pembukaan lahan untuk permukiman, pertokoan, perikanan, dan pertanian dapat mempengaruhi lepasnya cadangan karbon ke atmosfer sehingga terjadi peningkatan kosentrasi gas $\mathrm{C} 02$ yang mengakibatkan bumi menjadi panas. $\mathrm{H}$ al ini menyebabkan terjadinya bencana hidrometerologi seperti banjir, 


\section{3}

Iongsor, puting beliung, dan kekeringan, rob dan lain sebagainya (H ermon, 2018).

Kota M alang merupakan salah satu daerah yang memiliki intesitas bencana seperti banjir genangan dan tanah longsor di beberapa kecamatan seperti Blimbing, Sukun, Kedungkandang, Lowokwaru, dan Klojen. M enurut U taya Sugeng (2008) banjir genangan dan tanah longsor terjadi karena proporsi lahan terbuka di Kota M alang semakin sempit serta sistem saluran drainase yang tidak memadai (D ewanto \& M uslim, 2013). Predikat Kota M alang sebagai kota pendidikan menyebabkan semakin padatnya pemukiman. A kibatnya banjir seringkali menimbulkan kemacetan lalu lintas, rusaknya infrastruktur jalan raya dan terganggunya aktifitas perekonomian warga. Selain itu curah hujan yang relatif tinggi pada bulan Pebruari, Nopember, Desember dengan perkiraan 201 - 300 mili meter hingga M aret 2017 (BM KG Stasiun K limatologi M alang, 2017) menyebabkan beberapa wilayah seperti Kota Lama, Polehan, Jodipan, Sukun dan Bareng sering terjadi banjir dan longsor.

Salah satu daerah yang berada di area perkotaan $\mathrm{M}$ alang namun sering dilanda banjir adalah kelurahan Bareng khususnya di kawasan RW VII dan RW VIII. Disetiap musim penghujan, Kelurahan Bareng selalu mengalami bencana banjir. Bencana ini sangat berdampak pada kehidupan ekonomi masyarakat yang pada kondisinya merupakan kawasan yang termasuk dalam kategori kumuh dan padat penduduk.

Artikel ini akan menjelaskan penyebab bencana banjir serta dampaknya terhadap perekonomian masyarakat Kelurahan Bareng. Dari dampak tersebut akan dijelaskan tentang bagaimana pengembangan ekonomi yang kompatibel dengan keadaan dan kebutuhan masyarakat Kelurahan Bareng.

A kifitas perekonomian suatu daerah atau wilayah sangat mempengaruhi volume produktifitasnya, artinya bahwa semakin meningkatnya permintaan barang dan jasa pada suatu kawasan akan terus mendukung pertumbuhan perekonimiannnya. Sebaliknyajika aktifitas perekonimian tidak mengalami peningkatan bahkan penurunan maka jumlah permintaan barang dan jasa akan semakin mengalami penurunan. Oleh karena itu kegiatan basis ekonomi memberikan pengaruh yang pertama dan utama serta memberikan dampak signifikan terhadap pergerakan volumekegiatan selanjutnya dalam jan gka pendek maupun jangka panjang.

Blakely dan Bradshaw mengatakan pengembangan ekonomi lokal merupakan proses dimana pemerintah lokal dan organisasi masyarakat terlibat untuk mendorong, merangsang, memelihara aktivitas usaha untuk menciptakan lapangan pekerjaan, maka pengembangan ekonomi lokal layaknya akan menciptakan usaha usaha baru melalui 
lembaga atau organisasi masyarakat. Menurut Blakely, ada 6 tahap dalam proses perencanaan pembangunan ekonomi daerah, pertama pengumpulan dan analisis data, kedua pemilihan strategi pembangunan daerah, ketiga pemilihan proyek-proyek pembangunan, keempat pembuatan rencana tindakan, kelima penentuan rincian proyek, keenam, persiapan perencanaan secara keseluruhan dan implementasi. (Blakely, 1989 dikutip dari Kuncoro, $2004:$ 49)

Perencanaan pembangunan ekonomi daerah bertujuan untuk memperbaiki penggunaan berbagai sumber daya publik yang tersedia di daerah tersebut. M elalui perencanaan pembangunan ekonomi daerah, suatu daerah dilihat secara keseluruhan sebagai suatu unit ekonomi (economic entity) yang didalamnya terdapat berbagai unsur yang berinteraksi satu sama lain. (Kuncoro, 2004 : 46). Sehingga perlu diperhatikan juga aspek ruang (space) atau lokasi dalam pelaksanaannya, dengan demikian pembangunan ekonomi selain bertujuan untuk meningkatkan pertumbuhan juga untuk meningkatkan target pemerataan. (Arsyad, 1999 : 109).

Selanjutnya menurut $\mathrm{H}$ ani $\mathrm{H}$ andoko, pengembangan sumber $\mathrm{D}$ aya manusia dalam suatu organisasi masyarakat, pada hakikatnya adalah upaya untuk merencanakan (planning) meningkatkan kemampuan dengan pendidikan dan pelatihan (education dan training) dan mengelola (managemen) masyarakat sehingga masyarakat lebih produktif. (Yogyakarta, BPFE, $2009 \mathrm{hlm}$. 117)

Berdasarkan kajian-kajian tersebut maka dalam melakukan pemetaan ekonomi masyarakat terdampak bencana, penulis mencoba untuk melakukan identifikasi yang lebih mendalam untuk mengetahui bagaimana fakta potensi sumber daya manusia jika dilihat dari sudut pandang yang berbeda karena mereka dihadapkan dengan kendala atau permasalahan yang lebih kompleks pada kondisi lingkungan yang tidak menentu. Berikutnya adalah mengenai pemetaan potensi Sumber daya alam yang dapat dilihat dari variabel peluang bahan baku, transpotasi, keberadaan pasar potensial dan potensi kewilayahan yang lainnya. Pada dasarnya variabel-variabel yang mempengaruhi dapat muncul dari hasil pendekatan identifikasi permasalahan.

M aka dengan mengidentifikasi permasalahan-permasalahan atau ken dala yang dialami warga dari sudut pan dang sumber daya manusia dan juga sumber daya alamnya diharapkan dapat meberikan gambaran pemetaan potensi-potensi peningkatan ekonomi masyarakat dalam ran gka peningkatan ketangguhan warga terdampak bencana.

Konsep dasar berfikir pada permasalah ini mengarah pada bagaimana kondisi sebenarnya tingkat atau level perekonomian warga Bareng sehingga dari kondisi tersebut 
dapat dirumuskan secara lebih fokus pada penetapan strategi peningkatan ekonomi. Kesesuaian tersebut sangat menentukan keberhasilan dari pelaksanaan progam yang akan dijalankan. Adapun indikator kesesuaian ini dapat dilihat dari bentuk program yang akan dijalankan berasal dari warga pada umumnya dan secara bersama-sama dapat mengimplementasikan perencanaan, kontrol, implementasi program dan mengevaluasinya sedangkan kesesuaian antara harapan peningkatan perekonomian dengan program-program akan berdampak pada pengembangan diferensiasi produk.

A dapun tujuan penunjukan responden yang digunakan dalam survei ini dengan sample total yang berdasarkan data acuan dari Kelurahan Bareng. Responden sedapat mungkin dipusatkan pada masyarakat terdampak bencana banjir untuk mendapatkan objektifitas dan realiabilitas data.

\section{METODE PELAKSANAAN}

Kajian masyarakat ini menggunakan M etode Perencanaan Partisipatif dengan pendekatan Rapid Rural A ppraisal (RRA) yaitu suatu metode pemahaman lokasi dengan cara belajar dari, untuk dan bersama masyarakat, untuk mengetahui, menganalisis dan mengevaluasi hambatan dan kesempatan melalui multidisiplin. D alam RRA, informasi dikumpulkan oleh pihak luar (outsiders), kemudian data dianalisa untuk menyusun perencanaan pembangunan yang sesuai potensi masyarakatnya. Pendekatan RRA bersifat penggalian informasi bersama-sama masyarakat mulai dari pengumpulan informasi, analisa sampai pada perencanaan program.

\section{HASIL DAN PEMBAHASAN}

Penyebab dan Dampak Banjir Terhadap MasyarakatKel urahan Bareng

Berdasarkan hasil survey pemetaan, pada segi infrastruktur, belum adanya dinding penahan menyebabkan air menggenang. Hal ini dikarenakan adanya aliran air dari berbagai sumber mata air diantaranya dari saluran drainase Perumahan Ijen Nirwana, saluran drainase Pulosari dan saluran air pemukiman Bareng. Hal tersebut diperparah dengan adanya sedimentasi/ en dapan di saluran air ditambah dengan perilaku masyarakat yang membuang limbah cair rumah tangga ke saluran. Genangan air menyebabkan berbagai kerugian, seperti masuknya air ke rumah warga, rusaknya perabotan rumah, tangga sebagai akses jalan menjadi licin sehingga membahayakan warga. Akses jalan menjadi terganggu dan tidak berfungsi. Kondisi ini juga dapat meningkatkan risiko pada kesehatan warga dan dapat menimbulkan longsor. 
Selain itu pada aspek ekonomi, kegiatan perekonomian masyarakat menjadi terganggu akibat air yang masuk di tempat usaha mereka. Keadaan ini berdampak pada pendapatan masyarakat yang berarti terjadi penurunan kapasitas perekonomian yang berimplikasi terhadap produksi domestik regional bruto. Secara psikologis, korban bencana mengalami kondisi traumatis yang dapat menghilangkan motivasi kerja serta dorongan untuk maju dan berkembang. Dalam hal ini diketahui bahwa dampak bencana bukan hanya pada aspek fisik seperti ban gunan, perumahan dan permukiman tetapi juga pada aspek sosial ekonomi, budaya dan psikologis.

Salah satu kegiatan penting dalam manajemen bencana terutama pada tahap pasca bencana adalah aktivitas rehabilitasi dan rekonstruksi. Tahap ini diawali dengan pengkajian kebutuhan pasca bencana (jitupasna). Dilanjutkan dengan pengkajian kebutuhan pemulihan dengan komponen pembangunan, penggantian, penyediaan bantuan akses, pemulihan fungsi, dan pengurangan risiko. $\mathrm{H}$ al ini dimaksudkan untuk men getahui kebutuhan prioritas rehabilitasi dan rekonstruksi dalam rangka memulihkan kembali seperti pada kondisi sebelum bencana. Jika dimungkinkan pada tahap ini untuk men ciptakan kondisi fisik, sosial, ekonomi serta psikologis masyarakat agar menjadi lebih baik dibandingkan sebelum terjadinya bencana.

Pada konteks Kelurahan Bareng yang terdampak bencana banjir dipandang perlu memulihkan kembali dan meningkatkan keadaan sosial ekonomi, budaya dan psikologis masyarakat sebagai aspek prioritas rehabilitasi dan rekonstruksi pasca bencana. M embangun menjadi lebih baik dan lebih aman (build back better and safer) yang terpadu dengan mengedepankan konsep pengurangan risiko bencana (disaster risk reduction). Pemulihan dilakukan melalui optimalisasi pemanfaatan sumber daya setempat sebagai pendukung pemulihan aktivitas sosial dan kemandirian masyarakat. Langkah ini tentunya dengan memperhatikan kondisi dan karakteristik sosial budaya masyarakat setempat.

Pemetaan Potensi Ekonomi Masyarakat Terdampak Bencana Kelurahan Bareng Kota Malang

Pada aspek Potensi Sumber D aya, elemen sumber daya yang memberikan kontribusi cukup besar antara lain sumber daya manusia, potensi sumber daya bahan baku, potensi wilayah, potensi iklim usaha, dan potensi pasar. Dari sisi sumber daya manusia, hasil survei lapangan yangtelah dilakukan menunjukan bahwa dilihat dari hubungan interaksi sosial antar warga tidak mendapatkan masalah yang menjadi hambatan terlaksananya pengembangan potensi ekonomi di kawasan kelurahan bareng. Perihal komiten, kerjasama 
dan juga dukungan lingkungan cukup besar mngarah pada usaha peningkatan perekonomian warga. Jika dilihat dari jumlah potensi sumber daya manusia produktif hampir sebanding dengan jumlah manusia tidak produktif. Namun lebih dari $80 \%$ warga menginginkan usaha men gembangan perekonomian secara berkelanjutan .

Kemampuan dan keterampilan warga bareng dalam mengelola bisnis dapat dilihat dari beberapa pertanyaan dan diskusi tentang bagaimana pengetahuan atau pengalaman yang mereka miliki dalam mengelola sebuah bisnis. Permasalahan yang sangat dominan adalah permodalan sebanyak kurang lebih 85\%, aspek lain seperti pemasaran, kapasitas produksi dan pengelolaan keuangan juga berada diposisi rata diatas $55 \%$. Hal ini mangamsumsikan bahwa warga pernah menghadapi permasalahan-permasalahan tersebut, dan dalam pengembangan usaha tersebut menjadi prioritas dibawah permasalahan modal. Maka sumber daya manusia Kelurahan Bareng dapat dikatakan siap dan mampu untuk menjalankan program pengembangan perekonomian tersebut.

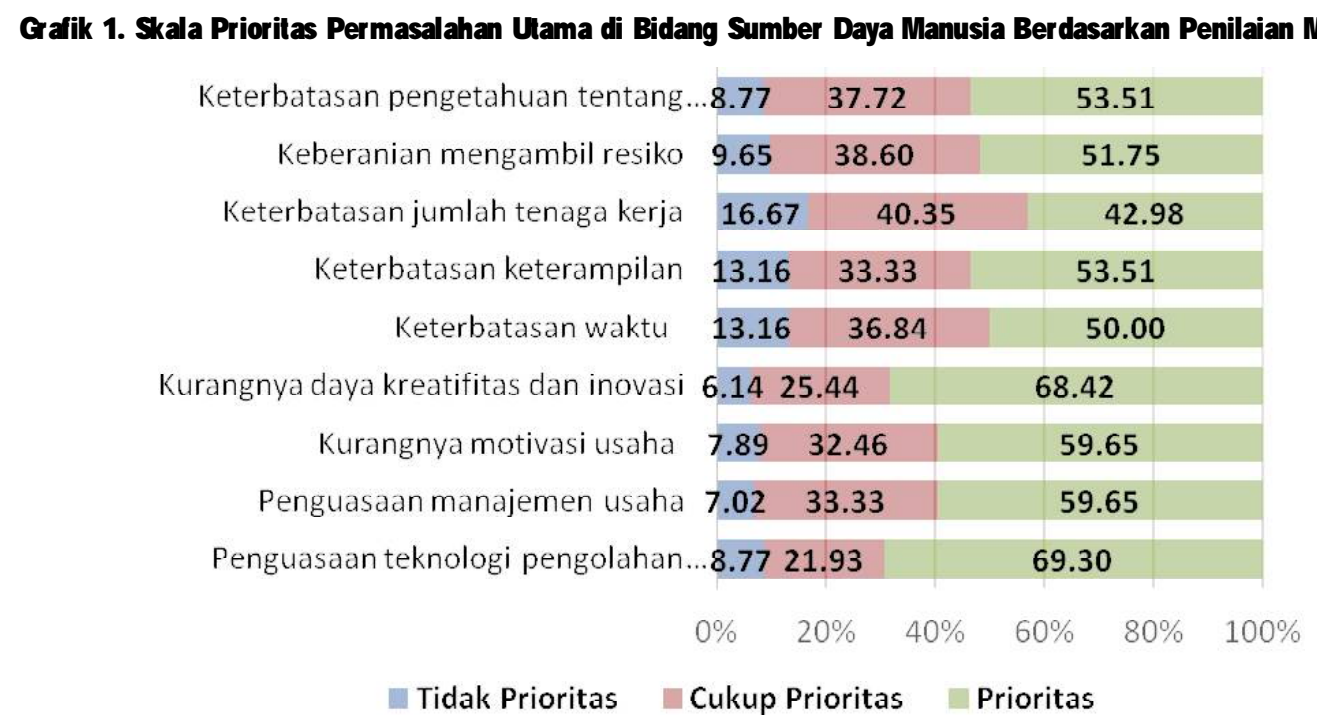

Sedangkan terkait potensi sumber daya bahan baku untuk produksi dalam skala kecil kondisi ketersediaannya di daerah Bareng masih cukup terjangkau dan cenderung akan mudah untuk didapatkan. $\mathrm{H}$ al ini didukung oleh posisi dan letak geografis dari Kelurahan Bareng yang berdekatan dengan sumber bahan baku, seperti Pasar Bareng, Pasar Besar, dan Pasar Comboran. H anya saja hal yang perlu diwaspadai dalam rangka menyediakan bahan baku adalah akses untuk mencapai lokasi atau tempat produksi, mengingat tata letak pemukiman kelurahan bareng yang sangat padat dengan kondisi gang yang sempit. 
Grafik 2.Skala Prioritas Permasalahan Utama di Bidang Produksi Berdasarkan Penilaian Masyarakat

\begin{tabular}{|c|c|c|c|}
\hline Akses menuju lokasi produksi maupun lokasipemasaran & 7.89 & 35.96 & 56.14 \\
\hline Kemasan Produk & 16.67 & 39.47 & 43.86 \\
\hline Penganekaragaman pengolahan produk & 9.65 & 42.98 & 47.37 \\
\hline Kebersilhan dan kesehatan proses produksi ] & 10.53 & 38.60 & 50.88 \\
\hline Teknologipengawetan & 25.44 & 36.84 & 37.72 \\
\hline Kemampauan memproduksi dalam jumlah besar & 15.79 & 37.72 & 46.49 \\
\hline Ketersediaan dan kualitas teknologi pengolahan & 13.16 & 39.47 & 47.37 \\
\hline Harga bahan baku y ang terjangkau2 & 2.6327 .1 & & 70.18 \\
\hline Ketersediaan Bahan baku & 9.65 & 34.21 & 56.14 \\
\hline
\end{tabular}

Potensi wilayah merupakan potensi yang sebenarnya memiliki kelebihan yang cukup berpengaruh. Bisa dikatakan lokasi wilayah Kelurahan Bareng berada di tengah Kota M alang, artinya pusat keramaian dan pusat aktifitas masyarakat Kota M alang dapat dengan mudah menjangkau wilayah Kelurahan Bareng. Kelancaran aktifitas produksi sangat dipengaruhi oleh akses perolehan bahan baku sampai akses kedatangan konsumen mudah dicapai, sehingga mempersingkat proses produksi mulai input sampai ke output serta meminimalkan biaya pengiriman bahan baku maupun barang jadi. $H$ anya saja karena tata letak pemukiman Kelurahan Bareng terbatasi oleh sempitnya akses jalan masuk untuk sebagian besarnya maka proses perpindahan barang yang memiliki volume besar secara fisik perlu diperhitungkan kembali. Namun hal ini menunjukkan juga bahwa bisnis dengan kapasitas atau volume besar kurang begitu cocok untuk diterapkan.

Dilihat dari potensi iklim usaha, berdasarkan hasil survei kehidupan sosial masyarakat bareng yang cukup dinamis dan juga status pekerjaan yang lebih banyak di sektor non formal menjadi salah satu fariabel yang menentukan bagaimana iklim bisnis yang diterapkan. $\mathrm{Hal}$ ini menunjukan hubungan yang signifikan antara pekerjaan non formal dengan hubungan atau interaksi sosial masyarakat. Pada umumnya area atau kawasan yang mayoritas bekerja pada sektor formal menunjukan hubungan interaksi sosial yang statis. Jadi, tentu iklim persaingan bisnis tentunya dapat diperkirakan akan ada pada hubungan persaingan yanglebih sehat karena peluang untuk men deferensiasikan produk cukup besar, artinya besar juga peluang untuk menciptakan produk yang berbeda karena ada pada segmentasi pasar yang cukup luas.

Sedangkan dilihat dari Potensi Pasar, Kelurahan bareng yang terletak di tengah pusat aktifitas Kota Malang sangat mendukung jarak kedekatan antara produk dengan 
konsumennya. Namun mereka menganggap bahwa pasar terdekat mereka khususnya radius M alang wilayah kota tidak mempunyai potensi yang besar. Buktinya produk yang pernah mereka coba untuk diproduksi dan dijual tidak terlalu diminati.

Pada dasarnya keberhasilan penetrasi pasar tentu perlu dukungan dari beberapa faktor yang menentukan. Faktorfaktor yang membantu keberhasilan penetrasi pasar antara lain, ketepatan kesesuaian produk yang diciptakan, strategi promosi, dan tentu faktor pelayanan yang prima. Jadi kedepannya terkait dengan potensi kedekatan pasar tersebut hendaknya mulai mengkalisifikasikannya pada segmentasi-segmentasi pasar tertentu.

Potensi U saha di Kelurahan Bareng terdapat tiga bidang utama yang diharapkan, pertama adalah bidang usaha perdagangan 89,5\%, kerajinan tangan 57\%, dan usaha jasa 57\%. Jadi ketiga bidang usaha ini dapat dikatakan layak untuk dilaksanakan.

D ari bidang usaha perdagangan yang diminati juga terdapat tiga besar jenis yang diharapkan antara lain pedagang kaki lima sebesar $86,2 \%$, warung kelontong $80,7 \%$, dan warung makan kuliner khas sebesar $67,5 \%$. Sedangkan dari bidangkerajinan tangan ada sebesar 45,6\% untuk daur ulang ban bekas, 44,7\% untuk jen is usaha koveksi dan $42,1 \%$ untuk anyaman dari bahan limbah RT. Lalu terdapat $43,9 \%$ usaha service elektronik, $40,4 \%$ salon dan potong rambut dan $38,6 \%$ pertukangan pada bidang usaha jasa.

D ari hasil survei menemukan beberapa pilihan bidang usaha dan juga bidang usaha yang diminati kurang dapat begitu fokus untuk diterapkan. Tentu diperlukan analisa yang mendalam untuk menentukan bidang dan jenis mana yang paling sesuai. Sangat tidak memungkinkan jika pemintaan ini dijadikan tolak ukur secara merata untuk mengakomodir semuanya. Diharapkan dalam analisa ini bisa menentukan prioritas bidang dan jenis usaha mana yang akan didahulukan. Variabel indikator yang sangat memungkinkan pengukuran kelayakan tersebut adalah asumsi atau prediksi produk nantinya kan berintegrasi dengan diferensiasi produk yang lain.

Volume usaha - Besar kecilnya bidang dan jenis usaha yang akan dijalankan sangat dipengaruhi oleh keseuaian antara potensi sumber daya yang dimiliki dengan luasnya pasar yang akan dibidik. Jika dilihat dari potensi sumber daya khususnya kewilayahan atau tata letak area tentu akan menjadi permasalahan yang mendasar jika akan menerapkan bisnis dengan kapasitas yang besar, keterbatasan area atau lokasi di rumah masing-masih warga ataupun tempat fasilitas umum tentunya perlu diperhitungkan kembali. Kecuali jenis produk mampu diproduksi di masing-masing rumah warga denngan kapasitas yang kecil lalu dikumpulkan di area yang lebih luas. Jadi dari analisa tersebut 
maka lebih memunginkan untuk menciptakan produk dengan kapasitas yang kecil atau bervolume kecil dengan keanekaragaman yang tinggi dan juga tingkat diferensiasi produk yang juga tinggi.

Produktifitas usaha adalah cerminan dari besar dan kecilnya sejumlah aktifitas untuk penciptaan sebuah produk yang efektifitasnya diukur melalui keseimbangan Anantara kualitas dan kuantitas. Dalam hal ini keterbatasanketerbatan sumberdaya manusia, sumberdaya bahan baku, teknologi dan lain-lain yang ada pada keluraha bareng tentunya dijadikan sebagai acuan dalam menentukan strategi bisnis pada produk tertentu. Sehingga ketika ada kesesuaian antara produk dan harapan konsumennya maka disitulah indikator keberhasilan dari produktifitas yang maksimal.

Potensi pengambangan usaha dikhususkan untuk mereka yang telah atau pernah atau sedang memiliki usaha sampingan. Pernyataan ini dimaksudkan agar kita dapat menggali kepada mereka sebagai pelaku bisnis tentang permasalahan yang sering menghambat mereka. Dari hasil wawancara tidak ditemukan bidan atau jenis usaha yang mengalami peningkata atau pertumbuhan yang signifikan mulai dari berdirinya usaha tersebut sampai sekarang. H asil survei juga menyatakan $79,55 \%$ dari mereka menginginkan untuk terus mengmbangkan usahanya. D alam perihal pengembangan usaha tentunya mereke telah memprioritaskan kepada hal-hal tertentu yang menjadi kendala utama dalam pengembangan bisnismereka. Terdapat 89,9\% dari mereka menyetakan memprioritaskan untuk penambahan modal, 89,9\% juga menyatakan akan meningkatkan volume usaha mereka, 86,49\% menyatakan ingin melakukan perluasan pasar dan 78,38\% akan membangun atau mengembangkan jaringan usaha melalui kemitraan. D ari keterangan tersebut ada empat rencana yang mereka prioritaskan untuk usaha pengembangan bisnis.

\section{Aspek bidang usaha}

U ntuk usaha yang sudah berjalan aspek bidang usaha tentunya menitikberatkan pada integrasi usaha yang memungkinkan. Integrasi ini bisa bersifat vertikal maupun horizontal. Pengembangan bisnis ini juga bisa mengarah pada pengembangan kapsitas jika memungkinkan. Khususnya pada warga bareng yang telah memiliki usaha terdapat sebanyak 97,3\% yang memiliki permaslahan permodalan yang ditujukan untuk pengembangan kapasitas. Pengembangan kapasitas ini perlu dianalisa kembali prioritasnya karena belum tentu pengembangan kapasitas tersebut sebanding dengan jumlah permintaan konsumennya. Terkadang obsesi untuk mengembangkan kapasitas ini hanya dikarenakan harapan mendapat keuntungan yang lebih besar. Perlu perhitungan yang 


\section{1}

lebih matang, dalam artian apakah jaminan perluasan pasar pasti ada maupun jaringan atau mitra bisnis yang mendukung seperti misalnya suplier bahan baku.
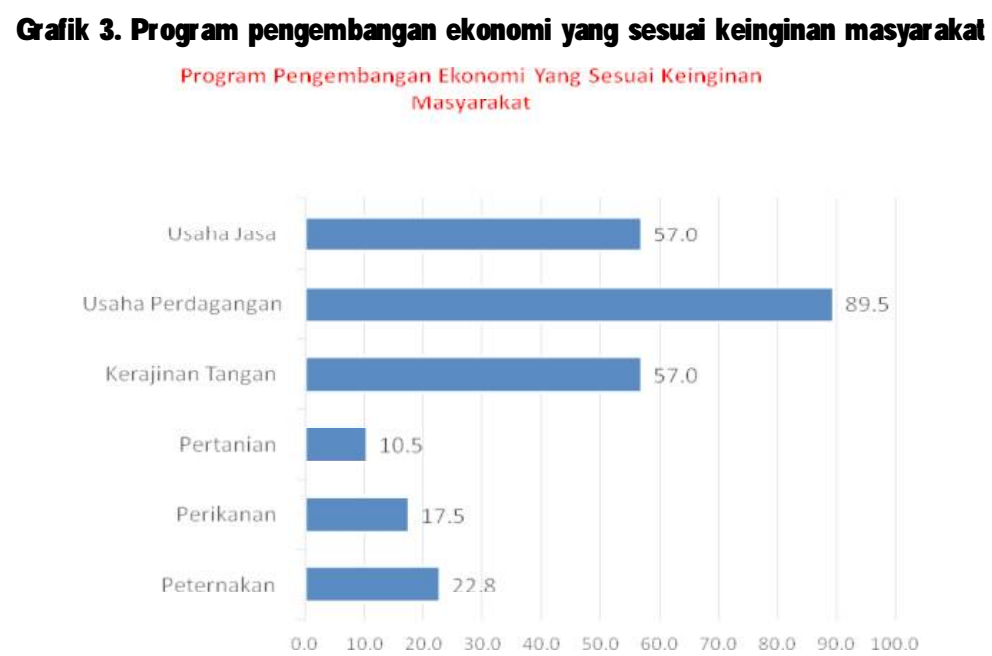

\section{Aspek jenis usaha}

Dalam hal pengambangan jenis usaha terdapat dua strategi yang dapat dilakukan, yang pertama adalah inovasi dalam artian memodifikasi produk utama untuk bisa mendapatkan segmentasi baru, pilihan strategi yang kedua adalah dengan cara menciptakan barang substitusinya atau barang pendukungnya yang masih terkait. Berdasarkan data yang didapatkan, motivasi untuk inovasi produk atau penganekaragaman produk lebih besar sebanyak $64,86 \%$ dibanding dengan menambah atau menciptakan produk baru sebesar $45,95 \%$. D ari angka tersebut dapat diartikan bahwa warga bareng yang sudah memiliki usaha tersebut masih ragu dalam inovasi produk atau mengembangkan ke produk baru. Jadi yang masi $h$ lebih banyak menjadi tujuannya adalah pengembangan kapasitas saja.

Grafik 4. Kerajinan tangan yang diminati

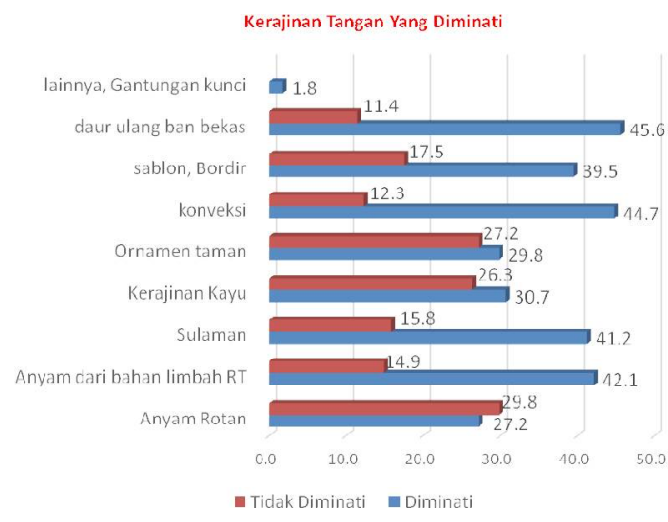


72

Jurnal BERDIKAR

Vol.7 No.1 Februari 2019

Grafik 5. Usaha jasa yang diminati Usaha Jasa Yang Diminati

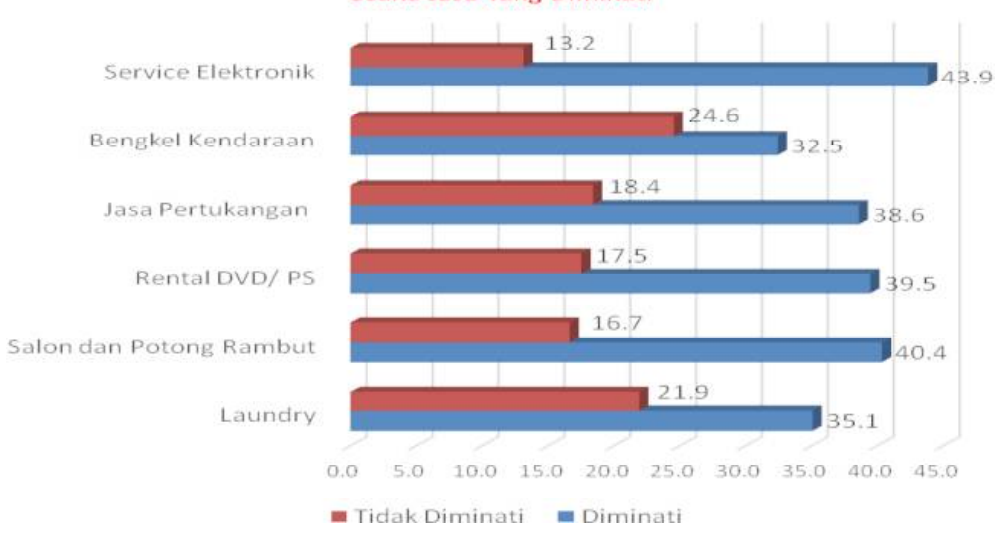

Grafik 6. Usaha perdagangan yang diminati Usaha Perdagangan yang diminati

Toko Pakaian Conter HP/ Pulsa

Kaki I ima Katering

Jajanan Pasar Warung Makan Kuliner Khas Warung Sembako/ Kelontong Usaha Kerupuk
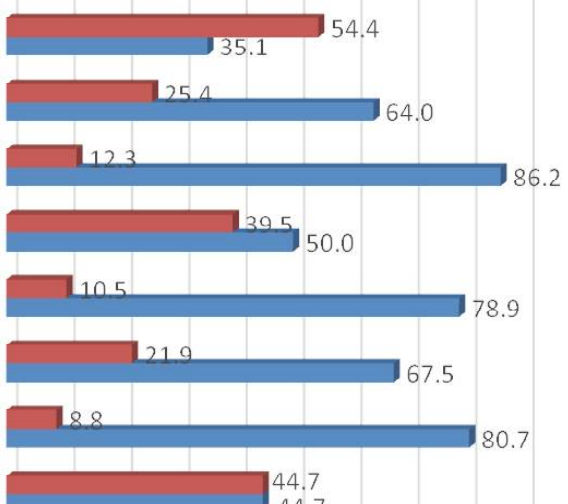

44.7

$\begin{array}{llllllllll}0.0 & 10.0 & 20.0 & 30.0 & 40.0 & 50.0 & 60.0 & 70.0 & 80.0 & 90.0\end{array}$

Tidak Diminati Diminat

Grafik 7. Budidaya peternakan yang diminati

Budidaya Peternakan Vang Diminati

$\square$ Tidak Diminati $\quad$ Diminati

Lainnya (Ayam dan Kambing)

lat

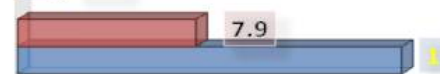

Burung

П.9

Tikus Putih

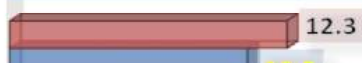

12.3

cacing Tanah

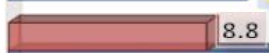

Kelinci

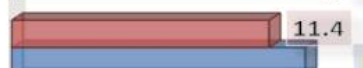


Gambaran permasalahan yang dihadapi

H asil survei menyatakan bahwa $71,05 \%$ warga Kelurahan Bareng menginginkan penciptaan usaha baru dan $28.95 \%$ mereka tidak menginginkan untuk menciptakan usaha baru dikarenakan merasa kurang sehat dan sudah berumur lanjut, mereka juga menyataka tidak memiliki waktu yang cukup untuk mengelola bisnis.

Permasalahan utama yang dihadapi adalah aspek permodalan dan variabel-variabel yang menentukan permasalahan ini antara lain secara berurutan menyatakan bahwa kurangnya modal usaha, prosedur pengrusan kredit, pengembalian kredit yang memberatkan, kurangnya akses informasi, dan kurangnya minat penanaman modal, menjadi masalah yang sampai saat ini belum mendapatkan solusi. Para calon pelaku usaha pada keluraha bareng menganggap kunci keberhasilan mereka untuk memulai dan mengelola bisnis adalah aspek permodalan.

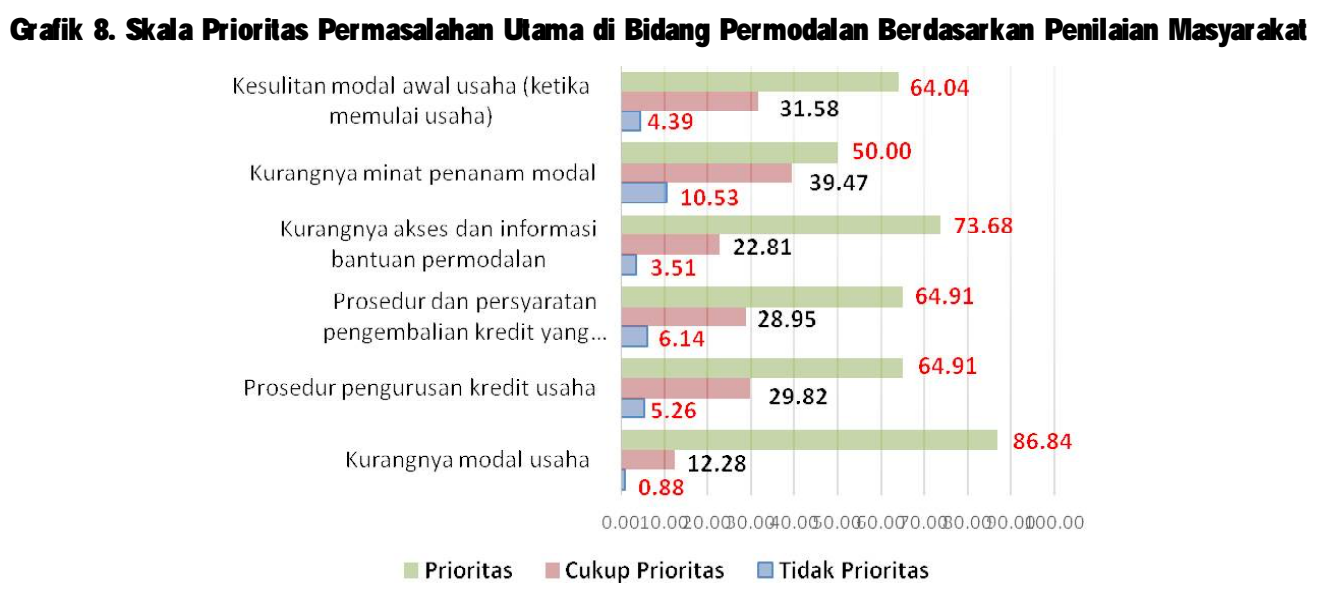

Sumber daya manusia masyarakat Kelurahan Bareng bisa dikatakan cukup tersedia, dalam artian jumlah orang usia produktif yang masih memiliki waktu untuk mengelola usaha secara mandiri ataupun kelompok masih tersedia. Berdasarkan hasil FGD menyatakan walaupun mereka yang sudah memiliki pekerjaan di sektor formal ataupun nonformal masih dapat menyediakan waktu untuk mengelola usaha sampingan. Terdapat sebagian besar usia lanjut yang merasa sudah tidak mampu untuk mengelola usaha, tetapi dirasa sebagian kecil saja.

D ari aspek sumber daya manusia permasalahan yang paling banyak dihadapi adalah mengenai penguasaan teknologi pengolahan produk sebanyak $69,30 \%$ dan juga mengenai kurangnya daya kreatifitas dan inovasi sebanyak $68,42 \%$. Sedangkan permasalahan yang lain seperti pengetahuan tentang pemasaran produk, keberanian mengambil risiko, 
keterbatansan keterampilan, keterbatasan waktu kurangnya motivasi dan penguasaan manajemen usaha juga menjadi permasalahan antara sebesar 40\%-50\%, hal ini menunjukkan bahwa sebenarnya sebagian besar mereka yang berpengalaman maupun yang tidak berpegalaman memiliki problematika yang sama. Pada dasarnya ketahanan mereka dalam men gelola dan mengembangkan usaha bisa dikatakan kurang. Kurangnya faktor pendukung seperti pelatihan manajemen usaha dan juga informasi dalam mengakses modal tentu menjadi pengaruh yang cukup kuat dalam permasalahan ini. Tetapi perihal ketersediaan dan minat yang ada pada warga Kelurahan Bareng menjadi modal utama dalam keberhasilan program-program yang akan dilakukan .

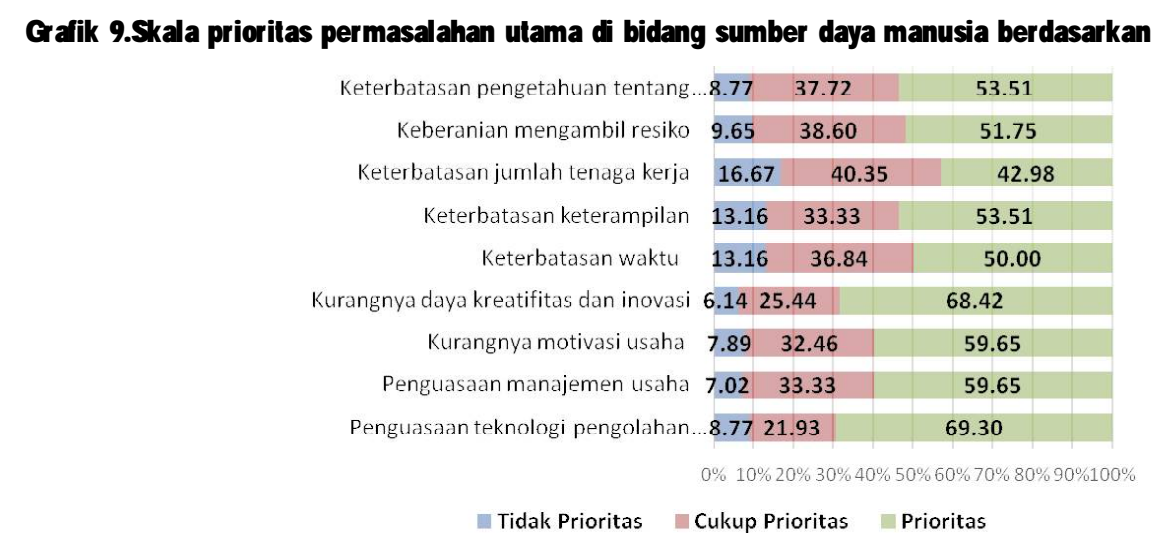

Permasal ahan lain yang muncul pada warga Kelurahan Bareng dalam mengelola usaha adalah teknologi. Pada dasarnya ketersediaan mengacu pada tingkat pengetahuan atau pengalaman yang mereka miliki. Ada dua kategori yang dapat diklasifikasikan pada permasalahan ini yang pertama adalah pengembangan teknologi yang berasal dari mereka sendiri, artina inovasi tekologi adalah hasil dari pengembangan modifikasi dari perhitungan dan pertimbangan mereka sendiri, hanya saja permasalahannya dikaitkan dengan permodalan. Yang kedua adalah perihal kurangnya pengetahuan dan informasi tentang teknologi dari pihak lain, tentunya permasalahan ini karena tidak adanya mitra atau pihak yang mendukung untuk pemikiran pengembangan usaha berdasarkan pengembangan teknologi. $\mathrm{H}$ al ini sesuai dengan hasil survei yang telah dilakukan menyatakan bahwa $61,40 \%$ mermasalahan utama terletak pada kurangnya akses dan informasi teknologi, sedangkan mengenai pemeliharaan teknologi, prosedur untuk mendapat distribusi bantuan tenologi, kualitas alat, dan ketersediaan teknologi tepat guna juga menjadi problem yang cukup merata sebesar 40-50\% diprioritaskan. 


\section{5}

Grafik 10. Skala Prioritas Permasalahan Utama di Bidang Teknologi Berdasarkan Penilaian Masyarakat

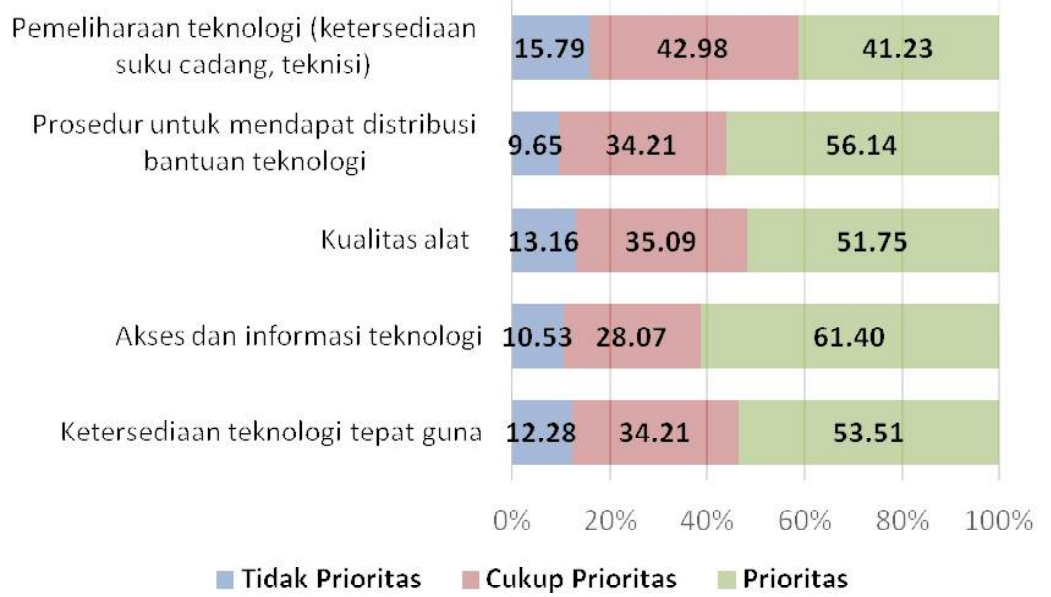

D alam menentukan segmentasi pasar tentu harus leih difokuskan pada definisi strategi bisnisnya, pada dasarnya masalah ketersediaan pasar tentu disesuaikan dengan produknya. Selama ini kebanyakan dari mereka yang telah memiliki pengalaman memproduksi produk pengikut saja, artinya produk yang mereka ciptakan menyesuaikan saja dengan pasar yang sudah ada. Maka terjadi persaingan yang sulit untuk dimenangkan, karen keterbatasan kapasitas yang dimilikinya. D ari hasil survei mengenai permasalahan utama di bidang pemasaran adalah menentukan pangsa pasar sebesar $54,39 \%$ dan juga penguasaan manajemen pemasaran sebesar $53,51 \%$ menyimpulkan bahwa sebenarnya produk yang dihasilkan, strategi yang dijalankan dan segmentasi yang dituju belum seimbang dengan harapan keuntungan. jadi pada dasanya karena permasalahan tersebut menjadikan taget pasar manjadi kurang tepat, dan penciptaan produk menjadi kurang maksimal, mereka hanya akan terus menurunkan harga jual dikarenakan mengikuti aktifitas pasar yang lebih besar.

Berdasarkan hasil survei, FGD dan pengamatan langsung yang dikaitkan juga dengan posisi kewilayahan Kelurahan Bareng maka sebenarnya masalah ketersediaan bahan baku tidak menjadi masalah yan g berpen garuh besar. $D$ ari beragam jenis usaha yang ada masi memungkinkan untuk dapat mengakses atau memenuhi bahan bahan baku yang diharapkan sesuai dengan batasan kapasitasnya. Permasalahan utama yang sebenarnya adalah harga bahan baku sebesar $70,18 \%$ artinya bisa jadi bahan baku yang memang berharga mahal materialnya ataupun karna fluktuasi harga bahan baku. Pada kondisi pasar yang belum fokus, aktifitas produksi yangjuga belum menentu, makan akan menjadi problem yang besar untuk membuat keputusan pembelian bahan baku. Pembelian bahan baku dengan jumlah besar ataupun kecil tentu menjadi masalah yang kompleks, ditambah lagi dengan biaya-biaya lain yang terkandung didalamnya. 


\section{REKOMENDASI}

Berdasarkan hasil survei maka bidang usaha yang telah ditekuni oleh masyarakat sebagai modalitas dalam pengembangan ekonomi, adalah

A. Bidang Ekonomi

1. Bidang usaha yang sudah ada (modalitas ekonomi)

Jika selama ini Sanan dikenal dengan produk Kripik Tempe, Dinoyo dikenal dengan produk keramiknya, makaKelurahan Bareng selama ini telah dikenal dengan penghasil Gethuk yang cukup terkenal di Kota Malang. Namun imbas dari perkembangan modernisasi membuat gethuk kurang diminati oleh konsumen menyebabkan usaha gethuk di Kelurahan Bareng tidak dapat bertahan lama. U saha yang pernah digeluti oleh masyarakat Kelurahan Bareng ini merupakan modalitas ekonomi yang dapat dikembangkan lagi sebagai sumber penghasilan. U ntuk itu, hal-hal yang perlu dilakukan yatu diversifikasi produk dari bahan gethuk.

2. Pengembangan usaha yang sudah ada

Berdasarkan data yang didaptkan beberapa contoh bidang dan jenis usaha yang pernah bahkan sampai sekarang masih berlangsung. Pada dasarnya beberapa bidang usaha ini belum mengakomodir warga secara lebih merata, hanya dikelola oleh sebagian kelompok kecil saja. Permasalahan lain yang didapatkan adalah kurangnya strategi bisnis yang disesuaikan dengan produk dan konsumennya. Maka dari fenomena tersebut diperlukan penataan kembali tatakelola atau struktur organisasi yang jelas dan efektif lalu menyesuaikan strategi bisnis dengan sekmentasi konsumennya secara berkelanjutan.

3. Pembukaan usaha baru yang diinginkan (program)

Untuk membuka bidang usaha baru tentu diperlukan perencanaan yang matang, berdasarkan hasil surve bidang usaha perdagangan, kerajinan tangan dan juga bidang jasa menduduki peringkat tertinggi, namun dari hasil FGD didapatkan informasi tambahan tentang bagaimana sebenarnya yan g lebih dapat untuk segera di prioritaskan untuk dijalankan. Untuk bidang usaha jasa yang juga menduduki peringkat tinggi ternyata hanya bersifat keinginan yang belum tentu mampu mengukur kemmpuan teknis pelaksanaannya, selanjutnya bidang usaha jasa yang diharapkan belum tentu dapat berdampak secara luas untuk warga, kecederungan hanya pada in dividu tertentu sangat memungkinkan, bidang usaha jasa dalam kapasitas kecil membutuhkan waktu yang lebih lama untuk mendapatkan konsumen yang lebih luas, artinya pengguna jasa tersebut cenderung hanya berasal dari lingkungan sekitar saja. 
Berdasarkan analisa tersebut maka rekomendasi yang diberikan lebih memfokuskan pada usaha perdagangan dan kerajinan tangan, pada bidang perdagangan jenis usaha yang paling memungkinkan untuk dijalankan adalah usaha jeniskuliner yang berupa makanan atau minuman khas ataupun makanan khas. Jenis usaha ini didukung oleh banyaknya keterampilan memasak yang dimiliki oleh warga, Kelurahan Bareng juga pernah menyandang sebagai daerah penghasil getuk malang. Dengan memfokuskan pada beragam jenis kuliner khas diharapkan dapat lebih berdampak luas untuk warga.

4. M odel pengelolaan usaha baru (program);

Pengelolaan usaha makanan dan minuman khas akan dikelola oleh kelompok yang bertugas sebagi fungsi pemasaran dan keuangan saja. Sedangkan operasional penciptaan produk dialankan oleh masing-masing jenis produk sesuai dengan kelompoknya. Kelompok inti bekerja fokus untuk memasarkan dengan cara online dan juga mengelola outlet (jika disediakan) sedangkan bagian keuangan secara administratif mengelola pemasukan dan pengeluaran uang. Kelompok pendukung sebagai yangmenciptakan dan memproduksi produk sesuai dengan jumlah permintaan dari kelompok inti. Kelompok pendukung minimal beranggotakan 3 orang.

5. M odel implementasi program (madiri, pendampingan/ fasilitasi, pilot project) M etode pendampingan lebih diharapkan warga Kelurahan Bareng dengan alasan dibutuhkan pendampingan intens secara berkelanjutan. Tahapan pertumbuhan dan pengembangan perlu dibuat atas dasar kesepakatan bersama. Tim pendamping membuat indikator capaian pada masing-masing tahapan pertumbuhan dan selalu mengevaluasi sampai pada titik dimana usaha ini mampu untuk bekerja secara mandiri.

\section{B. Bidang Sanitasi dan Lingkungan}

Berdasarkan hasil Focus $\mathrm{G}$ roup D iscussion (FGD), disimpulkan bahwa sebagian besar masyarakat sebenarnya menerima penataan lingkungan hidup sehat, melalui pengembangan sanitasi dengan model terpadu yaitu berupa Instalasi Pengolahan Air Limbah Komunal (IPAL-Komunal). N amun sebagian besar warga menyarankan bahwa:

1. Revitalisasi sungai disekitar RW 7 dan RW 8, dengan mengupayakan terwujudnya aliran sungai yang bersih dan sehat. Karena selama ini aliran sungai oleh warga difungsikan sebagai saluran pembuangan limbah rumah tangga dan limbah MCK, salah satunya melalui pembangunan IPAL Komunal.

2. Pembangunan IPAL Komunal hendaknya dimulai dari kawasan atas aliran sungai (bagian wilayah RT 15 RW 8), sehinggajika bagian bawah aliran sungai sudah dibangun 
IPAL tidak dikotori lagi oleh warga bagian atas.

3. M engingat rata-rata luas areal tanah dan bangunan yang dimiliki warga relatif sempit dan saling berdekatan, maka diharapkan agar pembangunan IPAL Komunal menerapkan teknologi yang memungkinkan septic tank yang dibangun tidak bocor dan mencemari sumber air bersih yang dimiliki warga.

\section{SIMPULAN}

Dengan memandang desa sebagai basis pengembangan ekonomi mikro yang sangat berpotensi untuk mewujudkan kesejahteraan masyarakat, maka perlu menelaah lebih dalam lagi menggali potensi dari sudut pandang yang sesuai dengan kondisi daerah. Berdasarkan temuan-temuan tentang permasalahan desa yang rawan akan bencana, pemetaan potensi-potensi pengamban gan ekonomi merujuk pada pilihan strategi bisnis mikro yang dapat menjamin kesinambungan usaha secara strategis dalam artian motivasi untuk mampu bertahan dan beradaptasi pada lingkungan pasar dengan ketidakpastian yang tinggi.

Pemetaan potensi ekonomi desa yang didasari oleh potensi fisik dan non fisik didalam pembahasan diatas diharapkan dapat mengedepankan keunggulan produk atau comptitive advantage pada persaingan pasar yang sangat ketat dan berubah-ubah. A dapun beberapa komponen pemataan potensi ekonomi yang paling berpengaruh antara lain; pertama, tentang komponen SDM yang dapat disimpulkan bahwasanya masyarakat desa tersebut tidak memiliki kompetensi dan pengalaman yang cukup dalam pengelolaan usaha sehingga berdampak pada tingkat keberanian pengambilan resiko yang sangat rendah dan kecenderungan mempermasalahkan pada keberadaan modal, kedua, tentang komponen potensi wilayah yang seben arnya masih masuk dalam wilayah pusat kota den gan inten sitas bisnis yang cukup tinggi tetapi karena dampak akibat bencana banjir yang berkelajutan dan juga tata letak yang tidak direncanakan yang memberikan kendala dan hambatan untuk pengembangan usaha dengan kapasitas atau volume besar.

Salah satu karakteristik produk yang memungkinkan untuk dijalankan misalnya dengan pengelolaan usaha makanan dan minuman khas (dengan strategi diferensiasi) dapat dikelola oleh kelompok yang bertugas sebagi fungsi pemasaran dan keuangan saja. Sedangkan operasional penciptaan produk dijalankan oleh masing-masing jenis produk sesuai dengan kelompoknya. Kelompok inti bekerja fokus untuk memasarkan dengan cara online dan juga mengelola pusat outlet. Sedangkan bagian keuangan secara administratif mengelola pemasukan dan pengeluaran uang seta pembagian profit 
berdasarkan tingkat kontribusi warga, badan usaha ataupun lembaga yang dibentuk bersama. Kelompok pendukung sebagai yang menciptakan dan memproduksi produk sesuai dengan jumlah permintaan dan tingkat kualitas dari kelompok inti. Dengan strategi pembagian tugas atau pekerjaan disetiap divisi tersebut akan menciptakan ketergantungan yang tinggi antar kelompok masyarakat untuk bersama mencapai keberhasilan bersama (bukan pengembangan bisnis individual).

M etode pendampingan dari pihak-pihak tertentu membutuhkan pendampingan yang intens secara berkelanjutan. Tahapan pertumbuhan dan pengembangan perlu dibuat atas dasar kesepakatan bersama. Tim pendamping mengarahkan pembuatan indikator capaian pada masing-masing tahapan pertumbuhan dan selalu men gevaluasi sampai pada titik dimana usaha ini mampu untuk bekerja secara mandiri.

M anfaat utama pemetaan pengembangan potensi ekonomi di daerah rawan bencana ini adalah memberikan gambaran kepada masyarakat bahwa salah satu usaha untuk menjadikan desa rawan tangguh bencana adalah melakukan penguatan ekonomi warga untuk mencapai masyarakat man diri, yang mengembangkan dan men goptimalkan serta keterpaduan tipologi di daerah rawan bencana. 